\title{
DESENTRALISASI: HARAPAN DAN TANTANGAN BAGI DUNIA PENDIDIKAN
}

\author{
Oleh: Abdurrahmansyah
}

\section{Abstract}

Decentralization is an issue often discussed by many people. It becomes a discourse moved to balance the hegemony of centralist concept that deeply rooted in Indonesia. The application of decentralization and autonomy program has many impacts on many aspects including the education decentralization. The education decentralization gives many hopes and challenges. It is expected that the education decentralization could solve the education problems faced up to now. But it is a challenge for the regional government because of the real condition of region doesn't always have good potential that can easily be improved. In that context, this writing will study of the autonomy correlated with the education decentralization. The study will be arranged specifically to the key question of what the form of education decentralization is and what the hopes and challenges of education decentralization are.

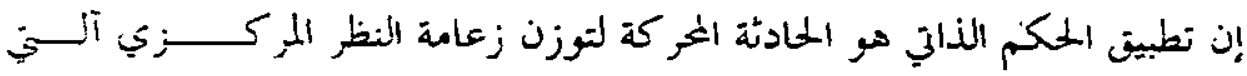

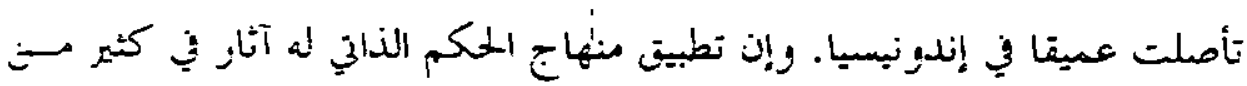
المطالع منها تطبيت منهاج التربية الإستقلالية، فالتربية الإستقلالية تذعو إلى الري ماء

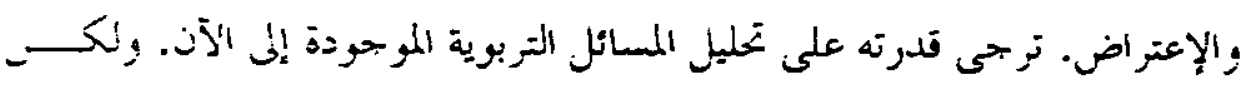

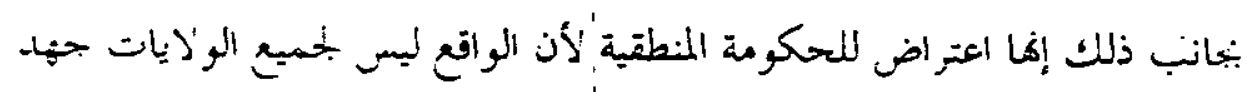

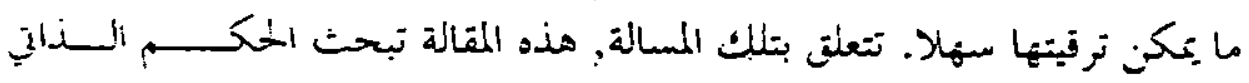

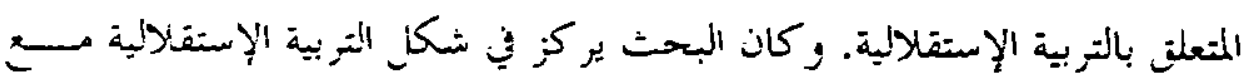
الر جاء والاعتر اضن منتها. 


\section{A. Pendahuluain}

Desentralisasi ${ }^{1}$ akhir-akhir ini marak diperbincangkan berbagai kalangan di tanah air sebagai wacana untuk mengimbangi hegemoni konsep sentralistik (sentralisasi) yang telah berurat berakar diberlakukan di Indonesia sejak kurun waktu yang lama. Urgensi wacana desentralisasi ini untuk menyadarkan kita akan pentingnya membangun sebuah dialog konsep yang pada gilirannya diharapkan dapat menjadi dasar bagi perbaikan konsep dan reformasi sistem penyelenggaraan sosial, termasuk di dalamnya penyeleng-garaan pendidikan.

Tema desentralisasi atau otonomi daerah jika berhasil direalisasikan dipastikan akan berpengaruh pada semua dimensi dan pranata-pranata sosial yang yang termasuk dunia pendidikan. Untuk kasus Indonesia, desentralisasi pendidikan dipandang perlu diperjuangkan sebagai tahapan awal mempersiapkan kualitas bangsa ini menghadapi konstelasi global yang semakin pesat perkembangannya. Hal ini dirasakan mendesak setelah mengetahui bahwa sistem penyelenggaraan pendidikan sentralistik yang lebih banyak didominasi oleh kebijakan dan wewenang pusat dalam pengaturan persoalan-persoalan pendidikan yang ada dipandang kurang relevan dikembangkan jika dihadapkan dengan tujuan-tujuan demokrasi pendidikan. Selain itu, konsep sentralistik di samping terkesan mengabaikan peran lokal, juga dianggap berpotensi melemahkan - untuk tidak mengatakan mematikan - semangat kreativitas daerah yang dalam sistem demo-desentralistik justru dipacu untuk berkompetisi secara sehat dan mandiri.

Wacana desentralisasi atau otonomi pendidikan ini dimunculkan sebagai antisipasi terhadap tantangan masa depan yang semakin kompetitif di mana perkembangan ilmu pengetahuan dan teknologi dengan pesat dengan menunjukkan temuan-temuan mutakhir yang semakin canggih.Realitas perkembangan ini tentu membutuhkan kesiapan manusia Indonesia untuk mengambil peran sebagai pelaku pada arus perkembangan itu. Untuk itu semangat kompetitif dan spirit kuriositas yang tinggi sangat dibutuhkan. Sedangkan semangat kemajuan dan progresivitas selalu muncul dengan baik dalam suasana yang kondusif dan bebas, dan bukan pada kondisi sosial yang selalu menekan (refresive) dan menindas, sebagai akibat lanjutan dari penerapan pengelolaan sosial yang dilakukan secara sentralistik-memusat.

Jika mengacu pada konsekwensi-konsekwensi yang terdapat dalam konsep desentralisasi dapat dipastikan bahwa sistem ini lebih berpeluang untuk semakin cepatnya proses penyelesaian problem-problem pendidikan di daerah dengan

\footnotetext{
' Sistem desentralisasi ini di beberapa negara Asia semisal Jepang ternyata telah dilaksanakan dalam waktu yang cukup lama yakni sebelum Perang Dunia II. Bahkan negera Jepang justru telah menerapkan konsep desentralisasi dengan kombinasi yang khas antara gaya Eropa dan gaya Amerika Serikat. Sistem otonomi daerah yang diterapkan di Jepang awalnya bertipe sentralisasi ala Eropa Daratan (seperti Perancis dan Rusia) dan setelah perang dunia II, tipe otonomi daerah di Jepang menjadi bercorak demokratis ala Amerika. Lihat Awani Irewati dan Bob Widyahanono, nBelajar Otonomi Daerah dari Jepang: Kombinasi Sistem Eropa-Amerika:, dalam Jawa Pos, Edisi 16 Maret 2001
} 
tidak terlalu membebani pemerintah pusat. Meskipun demikian, tentu ada beberapa kelemahan yang terdapat dalam sistem ini, terutama jika dihubungkan dengan kesiapan daerah dan kondisi riil lokal yang kenyataannya tidak selalu memiliki potensi-potensi yang baik yang dapat dikembangkan dengan mudah. Akan tetapi, dalam hal ini penulis setuju jika ada pernyataan bahwa kepađa siapa lagi persoalan-persoalan itu harus diserahkan dan diselesaikan jika tidak oleh yang bersangkutan, karena merekalah yang sesungguhnya yang lebih mengetahui problem dan potensi solusinya.

Tulisan sederhana ini mencoba memetakan sekitar wacana desentralisasi atau otonomi daerah dalam kaitannya dengan pelaksanaan otonomi pendidikan yang secara spesifik pembahasan ini akan diarahkan pada sebuah pertanyaan kunci, bagaimana bentuk pelaksanaan otonomi pendidikan dan apa saja tantangan dan harapan dari penerapan otonomi pendidikan ini. Pemetaan ini dipandang penting dikemukakan sebagai sebuah penetrasi kesadaran-kita untuk memasuki era baru dengan ciri dan karakteristik sosial yang amat berbeda dengan realitas sosial yang selama ini melingkupi kita secara sentralistik-menekan.

\section{B. Sekitar Wacana Desentralisasi Pendidikan}

Di Indonesia diskursus desentralisasi semakin mengemukakan dan secara bersemangat diperbincangkan peluang penerapannya setelah dikeluarkannya Undang-undang Nomor 2 tahun 1999 tentang Pemerintahan Daerah dan Undang-undang Nomor 25 tahun 1999 tentang Perimbangan Keuangan antara Pemerintah Pusat dan Daerah. Dan untuk melaksanakan UU Nomor 22 tahun 1999, telah dikeluarkan Peraturan Pemerintah Nomor 25 tahun 2000 tentang Kewenangan Pemerintah dan Kewenangan Provinsi sebagai Daerah Otonom, pada tanggal 6 Mei 2000. ${ }^{2}$

Dengan diundangkannya UU di atas menunjukkan kuatnya komitmen pemerintah untuk melakukan perbaikan dalam segi penyelenggaraan manajemen sosial di negeri ini. Menurut Fiske ${ }^{3}$, sekurang-kurangnya ada empat alasan rasional diterapkannya sistem desentralisasi sebagai sistem penyelenggaraan sistem sosial, termasuk pendidikan. Pertama, alasan politis, seperti untuk mempertahankan stabilitas dalam rangka memperoleh legitimasi pemerintah pusat dari masyarakat daerah, sebagai wujud penerapan ideologi sosialis dan laissez-faire dan untuk menumbuhkan kehidupan demokrasi. Kedua, alasan sosio- kultural, yakni untuk memberdayakan potensi masyarakat lokal. Ketiga, alasan teknis administratif dan paedagogis, seperti untuk memangkas

2. Lihat Peraturan Pemerimtah Republik Indonesia Nomor 25 Tahun 2000 tentang Kewenangan Pemerintah dan Kewerangan Provinsi sebagai daerah Otonom. Juga Undang-undang Republik Indonesia Nomor 22 Tahun 1999 tentang Pemerintahan Daerah. Lihat juga Undang-undang Republik Indonesia Nomor 25 Tahun 1999 tentang Perimbangan Keuangan Antar Pemerintah Pusat dan Daerah.

${ }^{3}$ Edward B. Fiske,1998, Desentralisasi Pengajaran: Politik dan Konsensus, Terj. A.B. Basilius Bengoteku, Grasindo, Jakarta. hal. 24-47. 
manajemen lapisan tengah agar dapat membayar gaji guru tepat waktu atau untuk meningkatkan antusiasme guru dalam proses belajar mengajar. Keempat, alasan ekonomis-finansial, seperti meningkatkan sumber daya tambahan untuk pembiayaan pendidikan dan sebagai alat pembangunan ekonomi.

Akan tetapi untuk kasus penerapan sistem desentralisasi pendidikan di Indonesia oleh beberapa pengamat justru melihatnya sebagai gejala keputusasaan pemerintah daląm menghadapi persoalan keuangan. Seperti yang dikemukakan Kacung Marijan ${ }^{4}$ misalnya, ia justru lebih melihat alasan dilaksanakannya otonomi pendidikan, khususnya desentralisasi pendidikan perguruan tinggi lebih karena alasan ekonomis-finansial. Hal ini dapat dilihat secara jelas dari titik berat otonomi Perguruan Tinggi yang lebih mengemukakan alasan untuk efisiensi dan efektivitas dari pada alasan untuk pengembangan ilmu pengetahuan dan teknologi. Padahal seharusnya sistem otonomi pendidikan lebih diarahkan untuk menumbuhkan semangat kompetitif di kalangan civitas akademika di perguruan tinggi dalam mengembangkan riset dan sisi-sisi keilmuan lainnya secara lebih leluasa.

Kekurangpuasan beberapa kalangan seperti Marijan, nampaknya cukup beralasan karena secara normatif pengertian desentralisasi menurut Soemardi HS $^{5}$ merupakan sebuah dorongan untuk meningkatkan kemampuan lokal (daerah) agar berpartisipasi secara aktif dalam upaya pembangunan daerah, serta memberikan kesempatan lebih luas kepada daerah untuk membuat perencanaan dan mengambil keputusan kebijaksanaan sendiri dalam menghadapi persoalan-persoalan mereka sendiri. Hampir senada dengan Soemadi, Fakry Gaffar ${ }^{6}$ mengemukakan pengertian desentralisasi sebagai sistem manajemen ${ }^{7}$ untuk mewujudkan pembangunan pendidikan yang menekankan pada keberagaman, dan sekaligus sebagai pelimpahan wewenang dan kekuasaan dalam pembuatan keputusan untuk memecahkan berbagai problemetika sebagai akibat ketidaksamaan geografis dan budaya, baik menyangkut substansi nasional, internasional atau universal sekalipun.

\footnotetext{
${ }^{4}$ Lihat Kacung Marijan, 2001, "Otonomi Kampus dan Elitisme Pendidikan", dalam Harian Jawa Pos, Edisi Rabu tanggal 4 April.

"Soemardi HS., 1990, "Relevansi Pendidikan Dicinjau dari Kepentingan nasional, Wilayah dan Peserta Didik", dalam Jumal Mimbar Pendidikan Nomor 3 Tahun IX OkTober hal. 26.

'Lihat Muhammad Fakry Gaffar, 1990, "Implikasi Desentralisasi Pendidikan Menyongsong Abad ke-21", dalam Jurnal Mimbar Pendidikan Nomor 3 Tahun XX Oktober hal. 18

${ }^{7}$ Menurut Slater terma sentralisasi dan desentralisasi pada dasarnya hanya sekedar penggambaran pembagian kekuasaan dalam organisasi atau sistem sosial. Gambaran tersebut sebenarnya masih rancu karena interpretasi yang bermada emosional dalam terminologi struktruralis. Lihat R.O Slater, "On Centralization and School Restruemuring: A Sociological Persfective", dalam H. Beare \& W. Lowe Boyd,1993, Restructuring School, The Falmer Press,London. haI. 175-180. Kerancuan itu dapat dipahami karena pembagian kekuasaan in merupakan suatu proses yang sangat politis, dalam arti distribusi kekuasaan itu tentu berpenganh terhadap pergeseran penggunaan berbagai sumber daya yang terbaras untuk memenuhi berbagai kepentingan yang saling bersaing. Dalam konteks pemerintahan, distribusi kekuasaan tersebut melibackan otoritas lokal dan otoritas yang lebin tinggi, yakni Pusat. Oleh karena itu wajar apabila sentralisasi dan desentrajisasi dipandang sebagai dua kontinum pusat kekuasaan semata-mata, dan bukart sebagai strategi manajemen. Lihat Udik Budi Wibowo, 2000. "Pergeseran Pengelolaan Pendidikan: dari Sentralistik ke Desentralistik", Jumal Dinamika Pendidikan, FIP-UNY, hal. 13.
} 
Dari beberapa pengertian yang dikemukakan, secara filosofis jelas bahwa sistem desentralisasi sebenarnya berpeluang untuk lebih terberdayakannya potensi lokal di samping sebagai jalan keluar yang jitu untuk menghindari kelemahan-kelemahan yang terdapat pada sistem sentralistik. Di antara kelemahan-kelemahan yang terkandung sistem pengelolaan pendidikan secara sentralistik, menurut Udik Budi Wibowo ${ }^{8}$ setidaknya dapat dipetakan sebagai berikut: pertama, keadaan geografis dan demografis Indonesia sebagai negara kepulauan dengan wilayah penyebarannya yang sangat luas, dengan konsekwensi besarnya jumlah satuan-satuan pelaksana pendidikan yang harus dikelola, besarnya jarak geografis dan administratif antara satuan-satuan utama Depdikbud di Pusat dengan satuan-satuan pelaksana pendidikan, sukarnya satuan-satuan administratif pusat untuk mengakses gambaran akurat mengenai kebutuhan-kebutuhan riil akan pendidikan di daerah dan sumber daya yang dibutuhkan, sehingga sulit untuk mengambil keputusan yang tepat tentang alokasi sumber daya pendidikan bagi satuan-satuan pelaksana pendidikan secara rinci. Kedua, adanya perbedaan yang bermakna antara provinsi dalam hal tingkat perkembangannya yang tercermin pada tingkat perkembangan pendidikan, tersedianya sumber daya administratif dan pendidikan lokal serta keadaan sarana dan prasarana perekonomian. Hal ini menimbulkan persoalanpersoalan di daerah-daerah tertentu menyangkut pemenuhan kebutuhan akan sumber daya, baik untuk keperluan administratif, penyelenggara pendidikan, maupun penyelenggaraan komunikasi yang harus ditangani secara khusus. Ketiga, pengelolaan sumber dana, sumber daya manusia dan sarana prasarana oleh satuan-satuan yang berbeda baik pada tingkat satuan struktur supra (BAPPENAS, BKN, Depertemen Keuangan), tingkat pusat Depdiknas, maupun pada tingkat provinsi (Kanwil). Sedangkan di satuan-satuan pelaksana pendidikan, sumber daya diperlukan dalam keterpaduan jenis, jumlah, mutu dan waktu penerimaannya karena keterkaitan mereka dalam penggunaannya untuk melaksanakan program pendidikan yang telah ditentukan. Selanjutnya penentuan dan pengelolaan operasional program-program pendidikan yang merupakan dasar bagi perencanaan dan pengalokasian sumber daya pendidikan terletak di tangan direktorat-direktorat jendral bidang pendidikan.

Dengan diterapkan sistem desentralisasi berarti kendala-kendala operasional yang sering dihadapi oleh sistem sentralistik sedikit banyak dapat diatasi. Selain itu, pengelolaan yang dilakukan oleh institusi yang paling dekat dengan daerah lebih memungkinkan untuk memberikan layanan pendidikan yang lebih berkualitas kepada masyarakat. Kenyataan seperti inilah yang oleh Wirt dan Kirst $^{9}$ disebut sebagai penyelenggaraan pendidikan yang lebih baik (...bet-

\footnotetext{
" Udik Budi Wibowo, 2000, "Pergeseran Pengelolaan Pendidikan: Dari Sentralistik ke Desentraliscik", dalam Jumal Dinamika Pendidikan, FIP-UNY No. 2 tahun VII, hal. 15

'Lihat Frederick M. Wirt \& Michiael W. Kirst, 1982, School in Conflict, McCutchan Publishing Corp., Berkeley, hal. 147
} 
ter education would be possible if more locally based), karena lebih berorientasi pada pemutusan problem pendidikan secara mendasar pada level masyarakat.

Dari sekilas paparan mengenai keutamaan sistem desentralisasi dalam dimensi pendidikan semakin tampak optimisme penerapan sistem ini sebagai tawaran alternatif utama mengeliminasi persoalan-persoalan pendidikan masyarakat. Namun pertanyaannya kemudian adalah apakah semudah itu penerapan sistem desentralisasi pendidikan ini. Yoyon Suryono ${ }^{10}$, dalam sebuah tulisannya agaknya berusaha secara imbang dan jernih dalam melihat dan memahami konsep desentralisasi dalam penerapannya, terutama untuk kasus di Indonesia. Bagi Suryono, ada kesulitan untuk menjelaskan arah kebijakan otonomi di bidang pendidikan. Pertama, kesulitan muncul karena ada dua bingkai otonomi yang berbeda, yakni frame otonomi daerah dan frame otonomi pendidikan. Kedua, kesulitan karena masih kurang jelasnya muatan otonomi pendidikan. Ketiga, kesulitan pada usaha menangkap kebijakan itu sendiri: kebijakan siapa dan pada level mana, sehingga sulit ditentukan ke mana arahnya.

Kesulitan-kesulitan untuk menjelaskan arah kebijakan otonomi atau desentralisasi seperti yang dikemukakan Suyono di atas dapat dilacak dari beberapa arah kebijakan otonomi pendidikan dalam konteks otonomi daerah sebagai berikut, di antaranya pertama, secara general otonomi pendidikan menuju pada upaya meningkatkan mutu pendidikan sebagai jawaban atas "kekeliruan" kita selama lebih dari dua puluh tahun bergelut dengan persoalanpersoalan kuantitas. Kedua, pada sisi otonomi daerah, otonomi pendidikan mengarah pada menipisnya kewenangan pemerintah pusat dan membengkaknya kewenangan daerah otonom (baik provinsi, kabupaten, maupun kota), atas bidang pemerintahan berlabel pendidikan yang harus disertai dengan tumbuhnya pemberdayaan dan partisipasi masyarakat. Ketiga, terdapat potensi tarik menarik antara otonomi pendidikan dalam konteks otonomi daerah daiam menempatkan kepentingan ekonomik dan finansial sebagai kekuatan taris menarik antara pemerintah daerah otonom dengan institusi pendidikan. Keempat, kejelasan tempat bagi institusi-institusi pendidikan perlu diformulasikan agar otonomi pendidikan dapat berjalan pada relnya. Dalam format otonomi daerah, wilayah provinsi memiliki otonomi terbatas, sedangkan wilayah kabupaten dan kota memiliki otonomi luas dan utuh. Kelima, pada tingkat persekolahan, otonomi pendidikan berjalan atas dasar desentralisasi dan prinsip school based management pada tingkat pendidikan dasar dan menengah; penataan kelembagaan pada level dan tempat yang tepat menjadi faktor kunci keberhasilan otonomi pendidikan. Keenam, sudah selayaknya jika kebijakan otonomi pendidikan harus bergandengan dengan kebijakan

"' Yoyon Suryono. 2000, "Arah Kebijakan Otonomi Pendidikan Dalam Konteks Otonomi Daerah", dalam Jumal Dinamika Pendidikan, FIP-UNY Nomor 2 tahun VII, bal. 6-8. 
akuntabiliti terutama yang berkaitan dengan mekanisme pendanaan atau pembiayaan pendidikan. Ketujuh, pada level pendidikan tinggi, kebijakan otonomi pendidikan masih tetap berada dalam kerangka otonomi keilmuan, otaonomi terbatas pengelolaan perguruan tinggi, dan otonomi perguruan tinggi menuju perguruan tinggi berbadab hukum dalam wacana paradigma baru manajemen pendidikan tinngi yang format implementasinya masih dalam tahap pencarian bentuk. Kedelapan, dalam konteks otonomi daerah, kebijakan otonomi pendidikan tinggi dapat ditempatkan bukan pada kepentingan daerah semata-mata melainkan pada kenyataan bahwa pendidikan tinggi adalah aset nasional. Kesembilan, secara makro, apapun yang terkandung di dalamnya, otonomi pendidikan tinggi haruslah menonjolkan keunggulan-keunggulan perguruan tinggi baik sebagai kekuatan moral, kekuatan ekonomi, bahkan bisa menjadi kekuatan politik yang mampu mewarnai mozaik perjalanan bangsa dan negara dalam mewujudkan pemerintahan yang bersih (clean governance)

Pemetaan Suryono terhadap kemungkinan ketertumpang tindihan dalam menentukan arah kebijakan otonomi daerah di satu sisi dan otonomi pendidikan di sisi lain, menarik dicermati sebagai acuan memformulasikan arah kebijakan masing-masing wilayah otonomi itu. Sebab tidak menutup kemungkinan "ketidak jelasan" arah kebijakan ini justru menjadi batu sandungan yang signifikan bagi efektivitas penerapan otonomi pendidikan.

Menurut Franscisca Kemmerer, sekurang-kurangnya ada empat bentuk desentralisasi (pendidikan). Pertama, dekonsentrasi, yani pengalihan kewenangan ke pengaturan tingkat yang lebih rendah dalam jajaran birokrasi pusat. Kedua, pendelegasian, yaitu pengalihan kewenangan ke badan quasi pemerintah atau badan yang dikelola secara publik. Ketiga, devolusi, yakni pengalihan kewenangan ke unit pemerintah daerah. Keempat, swastanisasi, berupa pendelegasian kewenangan ke badan usaha swasta atau perorangan. ${ }^{11}$ Dalam kasus pembicaraan desentralisasi pendiđikan di Indonesia sejauh yang telah dilakukan nampaknya cenderung mengambil bentuk yang terakhir, swastanisasi. Selain tidak terlalu rumit, bentuk ini terkesan hanya sekedar pemindahan pelimpahan kewajiban dari urusan pemerintah menjadi urusan masyarakat. Jika ini yang menjadi kecenderungan dari desentralisasi pendidikan kita, menurut Kacung Marijan, akan terjadi implikasi yang sangat besar dari konsekwensi itu. Di antara yang menjadi keprihatinan Marijan adalah ssemakin tumbuhnya gejala elitisme kampus.

Fenomena semacam elitisme yang ditakutkan beberapa kalangan sebagai konsekwensi desentralisasi pendidikan, khususnya dalam konteks otonomi pendidikan di Perguruan Tinggi (PT) ini dapat dengan mudah terjadi, karena

"Franscisca Kenmerer, "Decentralization of Schooling in Developing Nations", dalam The Encyclopedia of Education, hal. 142 
dengan kebijakan itu PT dituntut untuk swadana dalam menjalankan kegiatan kampus. Untuk itu, hal yang paling mudah dilakukan untuk mengoperasikan aktivitas akademik dengan baik adalah melalui kenaikan SPP bagi mahasiswa. Sebab untuk diingat, setelah otonomi dipastikan tidak ada perbedaan yang berarti antara SPP di PT Swasta populer dan SPP di PT Negeri.

Dampak sosial selanjutnya dari realitas itu adalah semakin berkurangnya kesempatan anak-anak dari kalangan menengah ke bawah untuk mengenyam pendidikan yang lebih berkualitas. Padahal secara filosofis, lembaga pendidikan tinggi merupakan salah satu instrumen pokok bagi kalangan menengah ke bawah untuk mengalami mobilitas vertikal. Dan jika ini terjadi, maka tujuan mendasar awal dari diterapkannya desentralisasi untuk meningkatkan efektivitas menuju kualitas bangsa, agaknya perlu dipertanyakan. Atau setidak-tidaknya kesiapan semua pihak untuk memikirkan secara serius gagasan desentralisasi ini menjadi semakin penting posisinya. Sebab seperti yang sinyalir Suyata, sangat boleh jadi desentralisasi menjadi terhambat oleh ketidaksiapan melaksanakannya seperti personil, dana, kelembagaan, dan dukungan secara substantif baik dari atas maupun dari bawah sendiri, atau disebabkan karena kekurang matangan dalam merencanakan konsep desentralisasi ini untuk situasi di masing-masing negara. ${ }^{12}$

\section{C.Desentralisasi Pendidikan: Peluang dan Tantangan Aplikasinya}

Menurut Yoyon Suryono, secara umum desentralisasi (otonomi) pendidikan berada dalam dua kawasan besar, otonomi pendidikan persekolahan dan otonomi pendidikan perguruan tinggi. ${ }^{13}$ Otonomi pendidikan di kawasan persekolahan dapat bernuansa dekonsentrasi, delegasi, devolusi, atau privatisasi.

Pada level lain, otonomi pendidikan persekolahan berlabel "school based management" atau "school site management" dengan fokus perhatian pada pengambilan keputusan pendidikan, proses belajar mengajar, sampai pada sistem pendidikan.

Untuk kasus persekolahan di Indonesia, seperti yang dilaporkan Bank Dunia (World Bank Report), praktek otonomi pendidikan pada level sekolah dasar (SD) justru telah dilakukan pada tingkat kabupaten, di mana para Bupati sebagai

kepala daerah di tingkat kabupaten memiliki tanggung jawab untuk melaksanakan program wajib belajar sembilan tahun. ${ }^{14}$ Meskipun belum maksimal pengelolaannya, akan tetapi program ini cukup efektif memberikan

12 Lihar Suyata, 1998, “Perbaikan Mutu Pendidikan Transformasi Sekolah dan Implikasi Kebijakan”. Pidato Ilmiah pada Dies Natalis XXXIV IKIP Yogyakarta, 23 Mei hal, 21.

13 Yoyon Suryono, op.cir., hal. 5

${ }^{14}$ Lihat Laporan Bank Dunia, Report No. 16433-IND, 30 Mei 1997. 
kesadaran baru bagi masyarakat tentang pentingnya partisipasi mereka dalam penyelenggaraan pendidikan. Dan bentuk partisipasi semacam ini akan lebih ideal jika berlanjut pada level-level pendidikan yang lebih tinggi. Karena sesungguhnya banyak pengalaman menunjukkan betapa signifikannya faktor budaya yang berkembang di masyarakat termasuk kultur kepedulian masyarakat seperti nilai-nilai progresivitas yang hidup di masyarakat, untuk berperan sebagai faktor penunjang atau justru sebagai faktor penghambat proses desentralisasi pendidikan ini. Dengan mengutip Kemmerer, Suyata mencatat kendala desentralisasi terletak pada kelambanan penguasa pusat sebagai resistensi pasif dan keengganan elit lokal-termasuk masyarakat pada umumnya-untuk mendukung desentralisasi tersebut. ${ }^{15}$

Karena keberhasilan dan ketidakefektifan-untuk tidak mengatakan kegagalan-desentralisasi sangat tergantung dari komitmen pemerintah pusat dan masyarakat lokal, maka sepertinya perlu menentukan beberapa kriteria pengembangan baru untuk memperlancar penerapan desentralisasi. Untuk kasus otonomi pendidikan persekolahan, menurut Don Adams, institusi sekolah mendesak untuk menginternalisasikan dan mengembangkan peranan baru dengan new skill yang meliputi: pertama, membangun kebutuhan untuk perbaikan terutama jika suplai terbatas (limited). Kedua, mengusahakan sumbersumber lokal. Ketiga, partisipasi dan berbagai informasi. Keempar, mengenali stakeholders. Kelima, pembagian kerja antar anggota stakeholders. Keenam, mengadakan diagnosis tentang kebutuhan dan dukungan masyarakat. Ketujuh, mengenali organisasi lokal yang ada. Kedelapan, merumuskan cara-cara memobilisir masyarakat. Kesembilan, mengembangkan teknologi perencanaan, pelaksanaan, dan pemantauan. Dan kesepuluh, mengembangkan kemampuan dan komitmen jangka panjang. ${ }^{16}$ Semua kemampuan baru yang harus dimiliki lembaga sekolah di atas merupakan langkah-langkah strategis untuk berperan dalam sistem desentralisasi pendidikan persekolahan. Dan untuk melakukan semua langlah itu membutuhkan pemahaman yang benar tentang kondisi sosio kultur masyarakat yang bersangkutan.

Selain itu, jika proses desentralisasi pendidikan persekolahan ini telah berkembang secara baik, maka berbagai bentuk pengelolaan keperluan sekolah (pendidikan) perlu dilaksanakan secara otonomis pula. Sebagaimana yang dikemukakan B.P. Sitepu misalnya, dengan menyoroti otonomi penyediaan buku pelajaran, ja secara lebih teknis menyarankan agar wewenang penyediaan buku pelajaran pokok untuk semua sekolah perlu diberikan kepada pengambil keputusan yang terdekat dengan sekolah. Otonomi penyediaan buku pelajaran

\footnotetext{
is Suyata, op.cir.

is Don Adams, 1998, "Education and National Development in Asia: Trends, Issues, Policies, and Strategies", (The Asian Development Bank, ), hal. 104.
} 
pokok ini dapat diberikan ditingkat kabupaten atau kota, kecamatan, bahkan di tingkat sekolah sesuai dengan kemampuannya masing-masing. Pemberian otonomi dalam penyediaan buku pelajaran pokok akan mengatasai berbagai masalah yang selama ini sulit dipecahkan. Selain itu, lanjut Sitepu, kebijakan sampai pada otonomi penyediaan buku pelajaran pokok ini dapat mengatasi masalah penyaluran dan ketidaksesuaian jumlah buku seperti yang terjadi selama ini. ${ }^{17}$ Gagasan desentralisasi pengadaan buku ajar ini juga secara akademis didukung penuh oleh Suryanto, sebagai upaya yang mampu memberdayakan kepala sekolah, guru, siswa, dan orang tua siswa. ${ }^{18}$

Namun barangkali kendala yang akan dihadapi oleh gagasan otonomi penyediaan buku pelajaran pokok ini adalah lebih pada kondisi belum tersedianya jaringan penerbit dan toko buku di semua daerah sehingga dapat mengakibatkan sulitnya memperoleh buku di daerah tertentu. Hambatanhambatan ini sesungguhnya dapat diatasi dengan usaha penerbit dan toko buku untuk mengembangkan jaringannya setidak-tidaknya sampai ke ibu kota kecamatan. Selain hambatan jaringan penerbit dan toko buku, terdapat lagi hambatan pelaksanaan otonomi pendidikan persekolahan yang tidak kalah seriusnya, yakni masalah sumber daya manusia (human resources). Oleh karena itu sangat penting menyiapkan atau menyediakan tenaga-tenaga yang baik di daerah yang mampu menilai buku pelajaran dari segi isi, metodologi, bahasa, dan grafikanya.

Di samping itu juga, masih dalam kaitan otonomi persekolahan, hal yang tidak kalah pentingnya adalah melibatkan secara signifikan upaya-upaya lokal dalam menyusun kurikulum dan mulai menganur sendiri penyusunan dan penyebaran bahan pembelajaran yang sesuai dengan konteks lokal. Untuk itu variabel-variabel tradisi, agama, kebudayaan, etnisitas dan cita-cita masyarakat dalam rancang bangun civil society tidak bisa diabaikan. ${ }^{19}$ Dalam perkembangan kurikulum, pakar dan pendidik dari semua daerah di Indonesia perlu didorong untuk lebih terlibat dalam penentuan isi kurikulum untuk konteks mereka sendiri. Oleh karena itu, pemikiran ini juga merekomendasikan agar Departemen Pendidikan Nasional (Depdiknas) meresmikan dan mendukung penggunaan lebih dari satu set buku paket. Sebab dalam kerangka pendidikan multikultural, sekolah seharusnya mempunyai kebebasan untuk memilih buku teks apa yang akan mereka gunakan.

"3.P. Sitepu. 2000, "Otonomi Penyediaan Buku Pelajaran", dalam Jumal Aralisis CSIS (Central for Straegic and Intemational Sudies). Tahun XXDX/ hal. 320.

1" Suryanto dan Djihad Hisyam, 2000, Refleksi dan Reformasi Pendidikan di Indonesia Memasuki Millenium III. Adicita, Yogyakarta. hal. 116.

"Anita et.al., 2000, "Keberagaman Budaya dan Otonomi Kurikulum", dalam Jumal Analisis CSIS (Central for Strategc and International Studies), No. 3 Tahun XXIX/, hal. 304. 
Sedangkan untuk konteks otonomi pendidikan perguruan tinggi, nampaknya sekarang sudah mulai diuji coba di empat perguruan tinggi di Indonesia, yakni Universitas Indonesia (UI), Institut Pertanian Bogor (IPB), Institut Teknologi Bandung (ITB), dan Universitas Gadjah Mada (UGM) sebagai pilot project. Terhadap keempat perguruan tinggi itu pemerintah merencanakan untuk mengubah statusnya menjadi badan hukum sendiri yang bentuknya dapat berupa perusahaan umum (Perum) atau perseroan terbatas (PT) seperti layaknya badan usaha milik negara (BUMN). ${ }^{20}$

Dalam beberapa hal mungkin terdapat berbedaan antara realitas otonomi pendidikan persekolahan dan otonomi pendidikan di perguruan tinggi. Seperti yang disinyalir Yoyon Suryanto, otonomi pendidikan diperguruan tinggi sekurang-kurangnya dapat dipahami dengan empat modus yang dimilikinya, yakni (1) kebebasan akademik dan otonomi keilmuan. (2) kewenangan menerima, menyimpan dan menggunakan dana yang berasal secara langsung dari masyarakat. (3) otonomi sebagai bagian penting dari paradigma baru manajemen pendidikan tinggi yang lengkapnya: quality, autonomy, accountability, acreditation, evaluation. dan (4) kewenangan mengelola secara mandiri bagi perguruan tinggi yang berstatus badan hukum. ${ }^{21}$

Dalam sisi legalitas formal, untuk mengatur bagaimana ruang gerak Perguruan Tinggi Negeri dalam menentukan kegiatan pendidikannya, pemerintah telah mengeluarkan Peraturan Pemerintah (PP) 61/1999 tentang otonomi perguruan tinggi yang akan menjadi dasar hukum perubahan status perguruan tinggi itu. Secara lebih rinci, dapat dijelaskan bahwa bentuk implementasi otonomi luas yang diberikan kepada perguruan tinggi antara lain: pertama, memberikan kesempatan kepada perguruan tinggi untuk mengisi muatan kurikulum sebanyak 30-40 persen dari muatan total yang mencirikan keunggulan kompetitif dan komparatif. Kedua, mendorong dikembangkannya program studi baru yang memiliki prospek sebagai pendorong perkembangan daerah melakukan peningkatan kemampuan mengembangkan sumber dayanya. Ketiga, mendorong dikembangkannya program studi jalur propesional dalam bentuk diploma III (D-3) atau politeknik. Keempat, mengembangkan budaya penelitian unggulan dalam bentuk kerja sama antara perguruan tinggi dengan pihak dunia usaha atau lembaga pemerintah dan non-pemerintah yang membutuhkan hasil kerja peneliti universitas.

Secara teknis ada dua hal yang penting diperhatikan dalam mengembangkan desentralisasi pendidikan di perguruan tinggi. Pertama, struktur organisasinya harus diperhatikan jangan sampai organisasi ini terlalu gemuk, sehingga gerakannya sulit sekali. Kedua, fungsi dari masing-masing unit dalam organisasi

\footnotetext{
${ }^{20}$ Harian Suara Pembaruon, Edisi 6 Juli 1999.

${ }^{21}$ Lihat Yoyon Suryono, op.cit., hal, 5
} 
di perguruan tinggi juga harus diperhatikan. Kedua hal ini harus dilakukan mengingat konsep otonomi perguruan tinggi menghendaki efesiensi dan efektivitas, sehingga dalam masa awal pelaksanaan otonomi ini dapat dengan tepat diperhitungkan perjalanannya agar tidak terjadi kesulitan-kesulitan teknis atau bahkan sampai kepada kemungkinan terburuknya, yakni colapsnya perguruan tinggi yang bersangkutan.

Memang harus diakui bahwa masih banyak yang perlu dibenahi oleh perguruan tinggi di Indonesia jika ingin dengan cepat menikmati pelaksanaan otonomi pendidikan di perguruan tinggi ini. Di antara yang mendesak untuk segera diperbaiki sejak awal adalah kualitas pelaksana pendidikan di institusi perguruan tinggi yang bersangkutan, termasuk di dalamnya para dosen, karyawan, dan staf pimpinannya. Mereka diharapkan dapat menempatkan diri sebagai sosok dari bagian civitas akademika yang profesional, dan berorientasi pada mutu pelayanan di bidang masing-masing. Kesiapan dasar ini selanjutnya dapat menjadi penilaian tersendiri bagi masyarakat dalam memberi kepercayaan pada perguruan tinggi sebagai lembaga akademik-ilmiah yang diharapkan dapat memberikan kontribusi bagi pengembangan kualitas bangsa di masa depan.

Dalam pada itu, tuntutan untuk segera membenahi diri ini juga berlaku untuk semua lembaga pendidikan di tanah airj termasuk institusi sekolah dalam semua level dari tingkat dasar sampai menegahj sebagai bagian dari sistem pendidikan nasional. Untuk itu suatu hal yang harus ditanamkan dalam benak semua kita adalah pemahaman bahwa pendidikan merupakan institusi yang penting bagi penyiapan dan peningkatan kualitas sumber daya manusia Indonesia yang benar-benar berkualitas. Kita perlu merenungkan kembali untuk menetapkan beberapa agenda esensiial pendidikan nasional agar dapat mengisi abad ke-21 tanpa keraguan akan masa depan generasi muda bangsa ini. Tanpa mempersiapkan masa depan mereka untuk hidup di millineum ke3 ini dengan berbagai keunggulan kompetitif yang harus dimiliki, bangsa kita akan tenggelam dalam setiap percaturan dunia yang semakin mengglobal.

Untuk itu pula, maka program pendidikan nasional yang amat strategis yaitu peningkatan relevansi, efisiensi, dan kualitas pendidikan yang tercover dalam semangat desentralisasi pendidikan adalah upaya mendasar yang sangat perlu disambut dengan antusias oleh semua insan akademik dan educationist di Indonesia. Sebab dari program ini agaknya bisa diyakinkan bahwa pendidikan nasional kita secara makro cukup menjanjikan bagi penyediaan sumber daya manusia (human resources) yang benar-benar memiliki keunggulan kompetitif. Lebih dari pada itu, sistem desentralisasi pendidikan yang akan mulai diterapkan ini sepertinya akan efektif membalikkan arah jarum jam sejarah politik pendidikan di Indonesia yang sejak beberapa kurun waktu terakhir cenderung larut dalam nuansa politik kenegaraan yang terkesan 
tidak demokratis, sehingga sistem pendidikan nasional di tanah air ini untuk waktu yang tidak pendek dipaksa untuk mengikuti kemauan pusat kekuasaan tanpa diberi peluang yang leluasa untuk menata pelaksanaan pendidikan yang sesuai dengan corak lokal masing-masing daerah di Indonesia.

\section{Penutup}

Konsep desentralisasi atau otonomi daerah yang telah dicanagkan dipastikan secara langsung akan berimplikasi pada dimensi pendidikan diharapkan mampu merealisasikan sistem desentralisasi pendidikan di Indonesia. Untuk itu berbagai perangkat perundang-undangan yang telah diberlakukan perlu dicermati secara serius oleh semua pihak, terutama insan pendidikan. Berbagai persoalan dan hambatan-hambatan teknis maupun kultural sedari awal perlu dibenahi dengan baik, karena sistem desentralisasi pendidikan akan selalu berorientasi pada kepentingan lokal di daerah di mana kesiapan lokal dipastikan sangat mempengaruhi sukses atau tidaknya penerapan desentralisasi pendidikan ini.

Karena merupakan wacana baru dalam konstelasi sistem pendidikan di Indonesia, sistem desentralisasi pendidikan ini tidak menutup kemungkinan akan menimbulkan berbagai hambatan, terutama berkaitan dengan kultur yang selama ini telah terbangun. Akan tetapi menurut hemat penulis, berbagai hambatan itu hanya merupakan persóalan biasa yang selalu berkaitan dengan sebuah wacana yang baru digulirkan. Padahal sesungguhnya secara moral sistem ini sudah lama dituriggu-tunggu oleh dunia pendidikan di Indonesia. Namun demikian, kerja keras berbagai pihak untuk menemukan strategi yang lebih efektif agar sistem ini bisa secara maksimal berhasil diterapkan juga merupakan sesuatu keniscayaan.

Akhimya, dengari melihat beberapa realitas yang ada yang menyangkut peluang dan hambatan keberhasilan penerapan desentralisasi pendidikan ini, penulis rasanya optimis jika sistem baru ini akan semakin mampu memperbaiki kualitas penyelenggaraan dan mutu out put pendidikan kita. Wallahu a'lam bi $a l$-Shawwab. 


\section{DAFTAR PUSTAKA}

Adams, Don, 1998, "Education and National Development in Asia: Trends, Issues, Policies, and Strategies", The Asian Development Bank.

Anita et.al., 2000, "Keberagaman Budaya dan Otonomi Kurikulum", dalam Jurnal Analisis CSIS (Central for Strategc and International Studies), No. 3 Tahun XXIX/.

Fiske, Edward B.,1998, Desentralisasi Pengajaran: Politik dan Konsensus, Terj. A.B. Basilius Bengoteku, Grasindo, Jakarta.

Gaffar, Muhammad Fakry, 1990, "Implikasi Desentralisasi Pendidikan Menyongsong Abad ke-21", dalam Jurnal Mimbar Pendidikan Nomor 3 Tahun IX Oktober.

Harian Suara Pembaruan, Edisi 6 Juli 1999.

Irewati, Awani dan Bob Widyahartono, 2001, "Belajar Otonomi Daerah dari Jepang: Kombinasi Sistem Eropa-Amerika", dalam Harian.Jawa Pos, Edisi 16 Maret.

Kemmerer, Franscisca, "Decentralization of Schooling in Developing Nations", dalam The Encyclopedia of Education,

Laporan Bank Dunia; Report No. 16433-IND, 30 Mei 1997.

Marijan, Kacung, 2001, “Otonomi Kampus dan Elitisme Pendidikan”, dalam Harian Jawa Pos, Edisi Rabu tanggal 4 April.

Peraturan Pemerintah Republik Indonesia Nomor 25 Tahun 2000 tentang Kewenangan Pemerintah dan Kewenangan Provinsi sebagai daerah Otonom.

Sitepu, B.P., 2000, "Otonomi Penyediaan Buku Pelajaran", dalam Jurnal Analisis CSIS (Central for Straegic and International Studies), Tahun $\mathrm{XXIX/}$

Slater, R.O, 1993, "On Centralization and School Restructuring: A Sociological Persfective", dalam H. Beare \& W. Lowe Boyd, Restructuring School, The Falmer Press, London.

Soemardi HS., 1990, "Relevansi Pendidikan Ditinjau dari Kepentingan nasional, Wilayah dan Peserta Didik", dalam Jurnal Mimbar Pendidikan Nomor 3 Tahun IX Oktober.

Suryanto dan Djihad Hisyam, 2000, Refleksi dan Reformasi Pendidikan di Indonesia Memasuki Millenium III, Adicita, Yogyakarta. 
Suryono, Yoyon, 2000, “Arah Kebijakan Otonomi Pendidikan Dalam Konteks Otonomi Daerah", dalam Jumal Dinamika Pendidikan, FIP-UNY Nomor 2 tahun VII.

Suyata, 1998, "Perbaikan Mutu Pendidikan Transformasi Sekolah dan Implikasi Kebijakan", Pidato Ilmiah pada Dies Natalis XXXIV IKIP Yogyakarta, 23 Mei.

Undang-undang Republik Indonesia Nomor 22 Tahun 1999 tentang Pemerintahan Daerah.

Undang-undang Republik Indonesia Nomor 25 Tahun 1999 tentang Perimbangan Keuangan Antar Pemerintah Pusat dan Daerah.

Wibowo, Udik Budi, 2000, “ Pergeseran Pengelolaan Pendidikan: dari Sentralistik ke Desentralistik", Jurnal Dinamika Pendidikan, FIPUNY.

Wirt, Frederick M. \& Michael W. Kirst,1982, School in Conflict, McCutchan Publishing Corp. Berkeley. 